\title{
Byzantine Military Pragmatism vs. Imperial Prejudice: Possible Reasons for Omitting the Armenians from the List of Hostiles in Maurice's "Strategikon"
}

\author{
Armen Ayvazyan \\ Matenadaran - the Institute of Ancient Manuscripts (Yerevan)
}

The problem of the various images of the Armenians in Byzantium has already become the subject of numerous, if sketchy, historical investigations and remarks. ${ }^{1}$ As a rule, students of this subject have focused on the images of those Armenians who resided beyond Armenia proper in the Byzantine capital and peripheral provinces as either newly-arrived immigrants or old-established inhabitants. Consequently, the shaping of the images of the Armenians in Byzantine Empire was appropriately sought and analyzed in such spheres as ecclesiastical differences between Armenian and Greek Churches, the ethnic peculiarities of everyday life as well as the rivalry in the imperial court between the Armenians and Greeks, the two major ethnic components of Byzantine elite. In contrast, this essay aims to analyze the Byzantines' image of the Armenians of Armenia, that is, those who continued to live in and exercise military and political authority over their homeland. Accordingly, this study focuses on the geopolitical determinant in the construction of Armenian images in the imperial strata of Byzantine society.

The "Strategikon", an influential manual of Byzantine military strategy attributed to Emperor Maurice (582-602), includes a separate chapter, in the words of the author, on "the tactics and characteristics of each race which may cause trouble to our state." ${ }^{3}$ The section deals specifically with "the Persians," "the Scythians, that is, Avars, Turks ${ }^{3}$ and others," "the light-haired peoples, such as the Franks, Lombards, and others like them," "the Slavs, the Antes, and the like."

Maurice's basic approach to these hostiles is down-to-earth military, often even highly complimentary about their particular martial traits. In spite of this pragmatism, however, all of these ethnically different peoples receive, to a greater or lesser degree, their dose of imperial prejudice, which itself was a necessary element for indoctrination of troops. Thus, the Persians, the old arch-enemy, are described as "wicked, dissembling, and servile"; ${ }^{4}$ the Avars as "scoundrels, devious..., treacherous, foul, faithless, possessed by an insatiate desire for riches..., very fickle, avaricious..."; ${ }^{5}$ the Franks and Lombards as "disobedient to their leaders," "easily corrupted by money, greedy as they are"; 6 the Slavs as having "ill feeling toward one another," "no regard for treaties," and hence "completely faithless" (this last reproach sounds especially hollow and cynical, because just a couple of pages earlier Maurice is advising his commanders to "pretend to come to agreements" with the enemy), "always at odds with each other."

In this depiction of hostile and troublesome peoples, the "Strategikon" conspicuously omits the Armenians, who had on many occasions fought the Byzantine troops either on their own or, more often, as allies or vassals of Persia. ${ }^{9}$ Furthermore, in the course of 
the $6^{\text {th }}$ century there were several uprisings in Armenian lands under the Empire's control. The rebellion of 538-539 stands out as perhaps the most prominent. First, the Armenians killed Acacius, who was appointed by the Emperor Justinian as head of their provinces. Then they assembled an army and took full control of the country. The Byzantine army sent by Justinian against them suffered a humiliating defeat near the Armenian town of Avnik (Procopius mentions it as Oenochalakon) in the westernmost edge of the heartland province of Ayrarat in Armenia proper. In this battle fought in the rugged terrain, the Armenians managed to kill the commanding general Sittas. ${ }^{10}$ The latter was one of Justinian's greatest generals. Procopius presents him as "a capable warrior, and a general second to none of his contemporaries" with "continual achievements against the enemy." "Defining Sittas as "a general second to none of his contemporaries," Procopius definitely had in mind the great generals Belisarius and Narses (who was an Armenian), with whom Sittas had an equivalent status and reputation during his lifetime. ${ }^{12}$ After the death of Sittas, Justinian was forced to send against the Armenians another army under Bouzes. ${ }^{13}$

During Maurice's own reign, three Armenian insurrections took place: 589, 591 and $601 .{ }^{14}$ Although they did not result in major hostilities and prolonged bloodshed, the military potential for Armenian resistance was evident as much as the unique combat capabilities of the Armenian troops, which were acknowledged by both the Romans and the Persians.

The absence of the Armenians from Maurice's list of hostile forces is all the more remarkable because contemporary Armenian primary sources have recorded verbatim his extremely negative attitude towards the Armenians. Maurice's critical depiction of the Armenians has been preserved in the seventh-century History of Bishop Sebeos. According to Sebeos, Maurice, in a special message to the Persian king and his ally Khosrov (Chosroes) II Parviz (590-628) proposed a conspiracy to destroy Armenia's armed forces by removing its military class, the nobility and their troops from Armenia and resettling them in remote areas of Byzantium and Persia. In his message, Maurice addresses the Persian king as follows:

A self-willed and recalcitrant nation lives between us and causes trouble. ${ }^{15}$ Now come: I shall mobilize mine [the Armenian princes and their troops] and send them to Thrace, while you would mobilize yours and send them to the East. If they perish, our enemies would perish; if they kill each other], they would kill our enemies, and we shall live in peace. For, if they remain in their country, we shall have no rest.

Then both [kings] have made an agreement [on the proposed policies]. ${ }^{16}$

Sebeos identifies this proposal as "the perfidious plot by Maurice to empty Armenia of Armenian princes." ${ }^{17}$ He also accentuates the bigoted character of Maurice's accusations, calling his message to the Persian king "the letter of vilifications about all the princes of Armenia and their troops." 18 
Byzantine and Persian policies towards Armenian nobility were carried out exactly in terms of Maurice's message to Khosrov II and correctly identified by both contemporary and modern historians as aimed at weakening Armenia and undermining its military establishment. ${ }^{19}$ The factual, if not textual, authenticity of Maurice's letter, including its strategic prescriptions, can thus be considered as historical reality. The content of this letter or the letter itself could have been passed to the Armenian leaders (and through them to Sebeos) by no one else than the same King Khosrov II, who immediately initiated a new war against the Byzantine Empire after the murder of Maurice. Khosrov needed the support of the Armenians and this letter would have served as an incriminating evidence against the ill intentions of Byzantium.

Further, Maurice's letter falls within an earlier Roman pattern of representing the Armenians as a historically defiant element against both Roman and Parthian/(later) Persian superpowers. Precisely the same leitmotif about the Armenian image resonates in the following comment by Publius (Gaius) Cornelius Tacitus (AD 56-ca AD 120):

Armenia... from the earliest period, has owned a national character and a geographical situation of equal ambiguity, since with a wide extent of frontier conterminous with our own provinces, it stretches inland right up to Media; so that the Armenians lie interposed between two vast empires, with which, as they detest Rome and envy the Parthian, ${ }^{20}$ they are too frequently at variance (emphasis is mine - A.A.).

[[Armenia] Ambigua gens ea antiquitus hominum ingeniis et situ terrarum, quoniam nostris provinciis late praetenta penitus ad Medos porrigitur; maximisque imperiis interiecti et saepius discordes sunt, adversus Romanus odio et in Parthum invidia. ${ }^{21}$

The same twofold anti-Iranian and anti-Byzantine attitudes of the independence-oriented Armenians are implicitly validated by the renowned commander-in-chief (sparapet) of the Armenian army Vasak Mamikonian (?-368), who after being treacherously captured by the Persian King Shapuh II (309-379) spoke to him as follows (the text is reported by Pavstos Buzand, the fifth-century Armenian historian):

...[While free] I was a giant, one of my feet rested on one mountain, the other on another mountain. When I was leaning on my right foot, I pushed the right mountain into the earth, and when I was leaning on my left foot, I pushed the left mountain into the earth.... One of those two mountains was you, and the other - the King of the Greeks [i.e. the Roman Emporer]... (the emphasis is mine) ${ }^{22}$

Notably, both Tacitus' and Emperor Maurice's judgments were uttered during periods of combined anti-Armenian policies conducted by Iranian and Roman/(later) Byzantine Empires. What they in fact superbly exemplify - vis-à-vis a full-fledged ethnonational consolidation of the Armenians in the historical periods under examination - is the 
important cross-cultural correlation of the frustration-aggression-displacement theory, known as "the more ingroup coordination and discipline, the more outgroup hostility." 23 These ethnic traits of the Armenians were pithily captured by Walter E. Kaegi, a prominent historian of Byzantine Empire, who did not omit to note that both the Arabs and the Byzantines had to take into consideration the "intractability and formidable character of the Armenians." ${ }^{24}$ Kaegi adds that "in no other region of the Byzantine Empire... did the local inhabitants have a tradition of being so well armed and prone to rely on themselves and their own family groupings and notables," noting also the Armenians' "impulse to local autonomy" and their "will to remain distinctively Armenian." 25

As the historical evidence cited above suggests the Armenians were fully qualified to be included in the "Strategikon"'s list of troublesome nations and their omission was certainly not a coincidence. To the best of my knowledge, the question of why they are absent from this list has never been posed before. Raising it can lead us to several important conclusions and suppositions. Below is a set of the possible answers.

1. Maurice's own Armenian origin, which has been a subject of contention, ${ }^{26}$ if true, could have prevented him from openly portraying the Armenians as a hostile people and, thus, attacking indirectly his own reputation.

2. The same motive should have been strengthened by the fact that the Armenians already constituted part of the Byzantine military and political elite: many Byzantine dignitaries and field commanders were of Armenian origin. As noted by P. Charanis, "Procopius mentions by name no less than seventeen Armenian commanders, including, of course, the great Narses." ${ }^{27}$ Although, as mentioned by the same author, the Armenian element in the Byzantine army was prominent in the armies of Justinian and Tiberius, "the situation changed in the course of the reign of Maurice, chiefly as a result of the Avaro-Slavic incursions into the Balkan peninsula. These incursions virtually eliminated Illyricum as a source of recruits and reduced the possibilities of Thrace. They cut communications with the West and made recruitments there most difficult. The empire, as a consequence, had to turn elsewhere for its troops. It turned to the regions of Caucasus and Armenia. In the armies of Maurice, we still find some Huns and also some Lombards. We find Bulgars too. But the Armenian is the element which dominates (the emphasis is mine - A.A.). ${ }^{28}$

For the success of his deliberate policies of resettling the Armenians into restless frontier regions of the Empire, mostly the Balkans and especially Thrace, Maurice was purposefully wooing the Armenian military. He relied heavily on their loyalty and military skills. ${ }^{29}$ Therefore, it would have been totally inappropriate to present them as a threat in a major tactics field manual for the officers, many of whom were Armenians.

3. In 591 Maurice imposed upon the Byzantine part of Armenian clergy the Empire's dominant Chalcedonite Christian doctrine. Again, the purpose was not a brutal suppression of Armenians, but their smooth Hellenization. Their portrayal as a hostile people would have harmed his ecclesiastical initiative as well.

4. The omission of the Armenians from the "Strategikon"'s list of hostile peoples could serve as further evidence in support of dating the composition of this military manual during Maurice's rule from 582 to 602 . If considered from this particular omission 
only, a more plausible time frame would have been after Persian King Khosrov II ceded parts of eastern Armenia to Maurice in 591, effectively making the Byzantine Empire the ruler of the larger part of Armenia and simultaneously turning the majority of the Armenians into the subjects of the Empire. After this, their open representation as a hostile people would have become nearly impossible. ${ }^{30}$

Thus, the Byzantine imperial prejudice against the Armenians, having been deliberately concealed and censored on the grounds of political and military expediency, did stay fully in place and provided ideological underpinning for the Empire's expansionist policies toward Armenia. However, as we have seen above, all this did not prevent traditionally independent-minded Armenians from correctly comprehending Maurice's conspiracy aimed at undermining Armenia's own military potential. Accordingly, the Armenians themselves defined Maurice as a hostile monarch and his Empire as fundamentally colonialist.

\section{Notes and References:}

1. For an excellent, though unfortunately short, essay, see Speros Vryonis, Jr., "Byzantine Images of the Armenians," in R. Hovannisian, The Armenian Image in History and Literature (Malibu, CA: Undena Publications, 1981), pp. 65-81; cf. A. П. Каждан, Армяне в составе господствующего класса византийской империи в XI-XII вв. (Ереван, 1975), с. 141; Nina G. Garsoian, "The Problem of Armenian Integration into the Byzantine Empire," in Hélène Ahrweiler, Angeliki E. Laiou, eds., Studies on the Internal Diaspora of the Byzantine Empire (Washington, DC: Dumbarton Oaks, 1998), pp. 66-67; Armen Ayvazyan, The Code of Honor of the Armenian Military, 4-5th centuries (Yerevan, Matenadaran: “Artagers," 2000, in Armenian), pp. 25-26, 40-41 (notes 52, 54).

2. Maurice's Strategikon: Handbook of Byzantine Military Strategy (The Middle Ages Series). Translated by George T. Dennis (Philadelphia: University of Pennsylvania Press, 1984), pp.113-126.

3. These would be the Turkic nomads "in the area east of the Black Sea and North of Persia" (see ibid., p. 116, note 3, referring to John Wiita, The Ethnika in Byzantine Military Treatises. Ph.D. diss., University of Minnesota, 1977, p. 122).

4. Ibid., p. 113.

5. Ibid., pp. 116, 118.

6. Ibid., p. 119.

7. Ibid., p. 120.

8. Ibid., p. 121-122.

9. It should be remembered that in 387 Armenia was divided between the Roman Empire and Sassanid Persia. The Persians took control of its major, eastern part, where the Kingdom of Armenia continued to exist until abolished in 428. The western part of Armenia fell under the Roman Empire's rule.

10. Procopius of Ceasaria, History of the Wars: The Persian War. Vol. I, Book 2 
(London: William Heinemann; New York : The Macmillan Co., 1914), pp. 272-277.

11. Ibid., p. 277.

12. On one occasion Sittas, together with Belisarius, fought and lost against another Narses (Nerses), an Armenian general in the Persian army (ibid., pp. 101, 139; for the military career of Sittas, see also pp. 131, 133, 137, 195, 197, 201). Sittas was well-acquainted with Armenian affairs, since in 529-531 he served in Armenia in the highest possible capacity of stratelates and magister militum per Armeniam (see Nicholas Adontz, Armenia in the Period of Justinian: The Political Conditions based on the Naxarar System. Translated from Russian by Nina Garsoian (Lisbon: Galouste Gulbenkian Foundation, 1970), pp. 108-111).

13. Ibid., 277.

14. See Eduard L. Danielyan, Political History of Armenia and the Armenian Apostolic Church (VI-VII Centuries), Yerevan, 2000 (in Armenian), pp.49-56; cf. The Armenian History attributed to Sebeos. Translated, with notes, by R. W. Thomson. Historical commentary by James Howard-Johnston. Assistance from Tim Greenwood. Part 1 (Liverpool Univ. Press, 1999), p. XX-XXI; Gabriel Soultanian, The History of Bishop Sebeos: Redefining a Seventh-Century Voice from Armenia (London: Bennet \& Bloom, 2007), p. 45.

15. Incidentally, the thesis about the recalcitrance of the Armenians was later reiterated by the Arabs, who mentioned the Armenian prisoners as "the worst among the white slaves." See А. Мец, Мусульманский Ренессанс (The Muslim Renaissance) (Moscow: Nauka, 1966), pp. 138, 140-141.

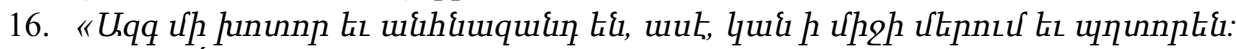

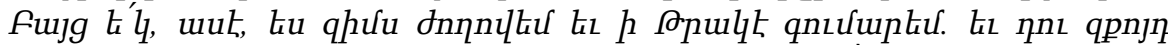

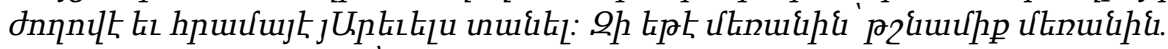

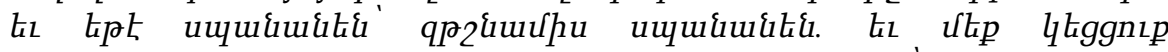

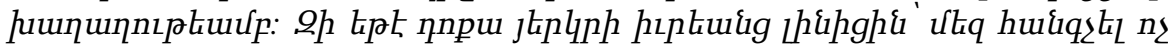

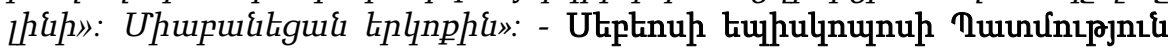
[The History of Bishop Sebeos], preparation of the text, the preface and commentary by G. V. Abgaryan (Yerevan, 1979), p. 86; cf. S. Malkhasyantz' publication of the same History (Yerevan, 1939), p. 49. Translation into English is mine. There are a few differences from other translations, including the translation of the word dnnnll $l_{L}$ as mobilize rather than gather, which makes clear Maurice's intention of gathering the troops rather than the Armenian civilian. For other translations of this passage into English, see Adontz, Armenia in the Period of Justinian, p. 166; Charanis, The Armenians in the Byzantine Empire (Lisboa: Livraria Bertrand, 1963), pp. 14-15; The Armenian History attributed to Sebeos, op.cit., p. 31.

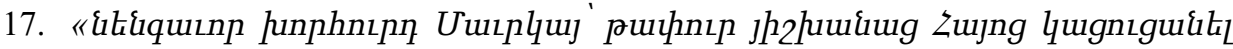
qZuju», - (The History of Bishop Sebeos, p. 86). R. Thomson translated this passage as "a letter of accusation... concerning all the Armenian princes and their troops" (The Armenian History attributed to Sebeos, op.cit., p. 31; earlier "a letter of accusation" was suggested by N. Garsoian, see Adontz, Armenia in the Period of Justinian, p. 166). There are two problems with this translation. First, the Armenian 


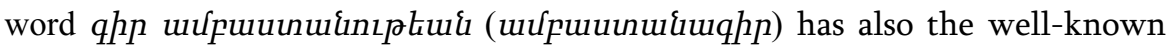
meaning of "libel," which corresponds much more adequately to this case. Second, Maurice's letter was specifically about the Armenian princes who were residing in Armenia proper and the Armenian original clearly uses the expression "of Armenia" (Zujuunuikiuug). The translation offered in this paper does also correspond to the historical context, because there were many Armenian commanders of princely status and origin in Byzantine military service, whom Maurice clearly did not have in mind, when writing his letter in question.

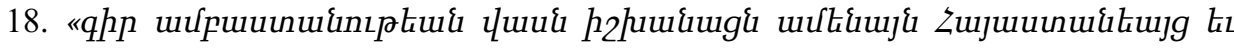
quipurg hiptuing» (The History of Bishop Sebeos, p. 86).

19. Adontz, Armenia in the Period of Justinian, op. cit., p. 159-161. Grousset R., Histoire de l'Armenie. Paris, 1947, p. 258. E. Danielyan identifies these policies as "the Maurice doctrine" (Danielyan, Political History of Armenia and the Armenian Apostolic Church, pp. 49-56). Recently, J. Howard-Johnston has advanced a revisionist interpretation of how "the recruiting process... worked to the Armenians' advantage" and, concurrently, rejected Sebeos' assessment of Byzantine and Persian empires' real intentions about Armenia (see The Armenian History attributed to Sebeos, pp. XX-XXI). These assumptions, however, are absolutely not convincing and, in fact, contradict the available historical evidence. The Byzantine policies of keeping their section of Armenia "under strictest guard and exhausted by unwanted taxes", removing the Armenians out of their country and scattering them "to every corner of the Roman empire" had been recognized by non-Armenian sources even before Maurice's more forceful policies to the same effect (see Procopius of Ceasaria, History of the Wars: The Persian War. Vol. IV, The Gothic War (London: William Heinemann; Harvard University Press, 1924), pp. 422-423.

20. The collocation of "in Parthum invidia" should be translated as "vie with the Parthian" rather than "envy the Parthian." Such a translation is more accurate in terms of historical context as well as the existing semantic option. The French translation of jalousie for invidia is a more adequate option: “...en Arménie. De tout temps la foi de ce royaume fut douteuse, á cause du caractère des habitants et de la situation du pays, qui borde une grande étendue de nos provinces, et de l'autre côté s'enfonce jusqu'aux Mèdes. Placés entre deux grands empires, les Arméniens sont presque toujours en querelle, avec les Romains par haine, par jalousie avec les Parthes" (Tacite, CEuvres Complètes. Tradirites en Fran des notes par J. L. Bunouf. Paris: Librairie Hachette, 1878, p. 79). For a detailed analysis of the existing translations (including those into Russian and modern Armenian) of this passage, see Armen Ayvazyan, The Cornerstones of Armenian Identity: The Armenian Language, Army and State (Yerevan: "Lusakn," 2007, in Armenian), pp. 107-110.

21. Tacitus, Annales. With an English translation by Clifford H. Moore (Cambridge, Mass.-London: Harvard University Press, 1969), II, 56, pp. 472, 474.

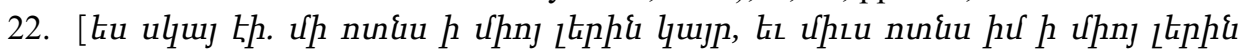

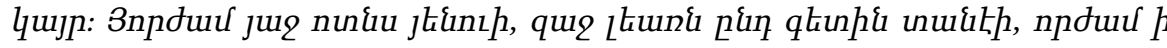




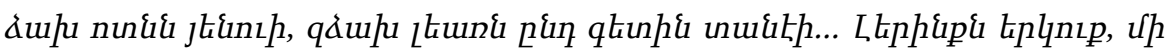

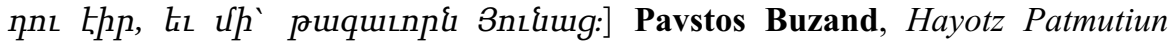
(History of Armenia), Tiflis, 1912, Book IV, Chapter 54.

23. See Robert A. LeVine and Donald T. Campbell, Ethnocentrism: Theories of Conflict, Ethnic Attitudes, and Group Behavior (U.S.A.-Canada: John Wiley \& Sons, Inc., 1972), pp. 124-125.

24. See Walter E. Kaegi, Byzantium and the Early Islamic Conquests, Cambridge University Press, 1992), p. 202, cf. a separate chapter on "Byzantium, Armenia, Armenians, and early Islamic conquests," ibid., pp. 181-204.

25. Ibid., pp. 189, 198.

26. Charanis, The Armenians in the Byzantine Empire, p. 14. For the historical analyses into the Armenian origin of Maurice, see Kaegi, Byzantium and the Early Islamic Conquests, p. 64. note 47.

27. Ibid., p. 16.

28. Ibid., p. 17.

29. In this connection it would be useful to recall that Maurice's predecessor, the Emperor Justinian was lenient in his treatment of Artavan Arshakuni (Artabanes Arshacid), the former Armenian rebel leader, to the point of dangerously exposing his own security. Even after the discovery of assassination plot against himself, Justinian did not severely punish him. For Artabanes' participation in the plot to kill Justinian, see Procopius, Vol. IV, The Gothic War (London, 1924), pp. 422-436. This overindulgence with the Armenian generals, who previously fought against his armies (according to Procopius, Artabanes was also possibly the one who personally killed general Sittas sent by Justinian against the Armenian army in 538/539), was clearly stemming from the same desire to use their skills and armed forces. Eventually, it was paying off, as in the cases of Artabanes, Narses and a great number of other talented generals of Armenian descent.

30. In this context, the hypothesis by John Wiita that the Strategikon was authored by Philippicus, general and brother-in-law of Maurice, between 603-615 (see Maurice's Strategikon, p. XVII), looks even less credible.

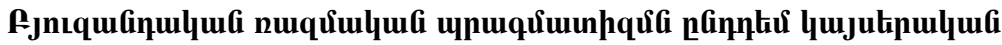 Güumuщzupuintfiph

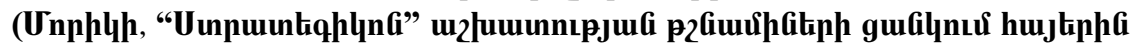

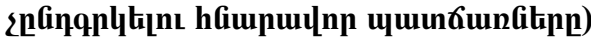

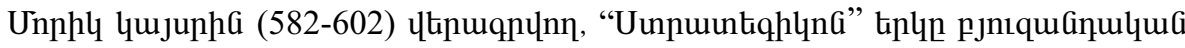

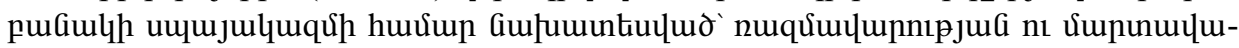

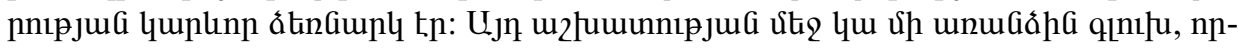

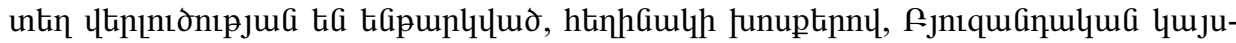

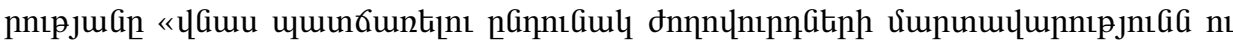




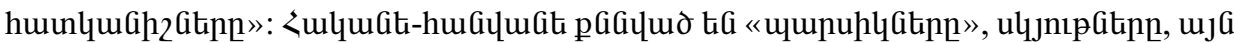

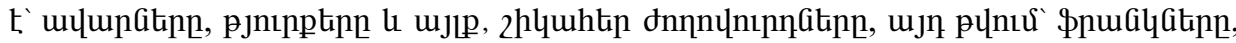

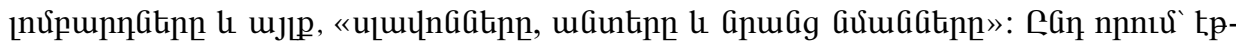

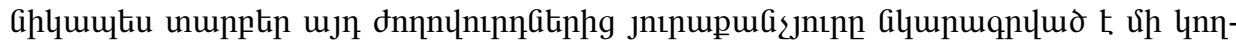

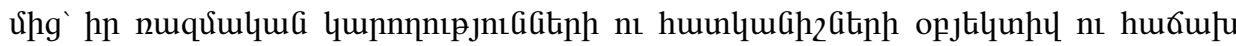

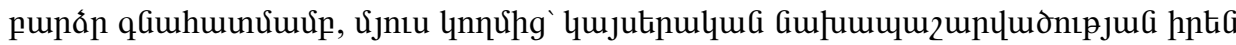

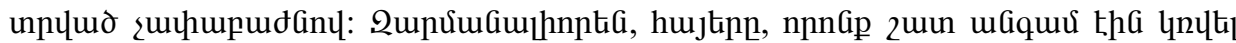

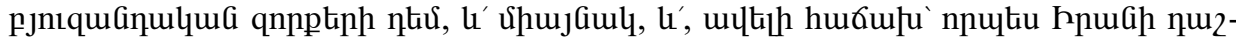

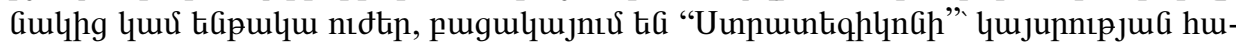

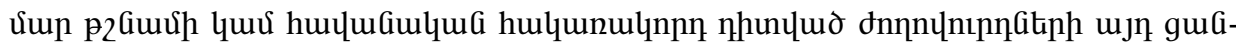

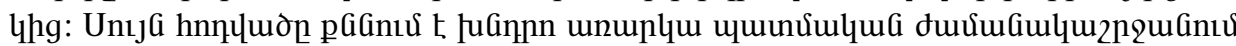

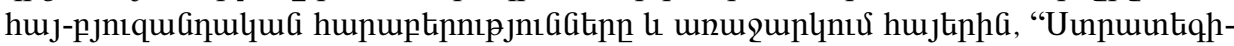

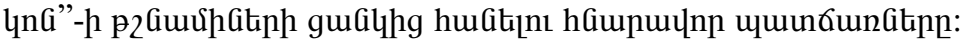

